\title{
Psoroptes sp. Infestation in Sulawesi Bear Cuscus (Ailurops ursinus) in Indonesia
}

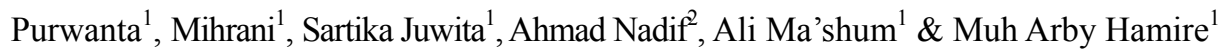 \\ ${ }^{1}$ Agriculture Extension College, Gowa, South Sulawesi, Indonesia \\ ${ }^{2}$ Agriculture Quarantine of Pare-Pare, South Sulawesi, Indonesia \\ Correspondence: Purwanta, Agriculture Extension College, Gowa, South Sulawesi 92171, Indonesia. Tel: \\ 62-8134-2408-306. E-mail: purwantadrhmkes@gmail.com
}

Received: May 13, 2014 Accepted: June 25, 2014 Online Published: July 2, 2014

doi:10.5539/ijb.v6n4p20 URL: http://dx.doi.org/10.5539/ijb.v6n4p20

\begin{abstract}
One male and two female sulawesi bear cuscus (Ailurops ursinus), weighing 4.4, 5.1 and $4.6 \mathrm{~kg}$ was admitted to the Animal Health Center of the Gowa Agriculture Extension College. Upon physical examination auricular skin lesions, and erythematous and pruritic skin lesions, both on the ventral abdomen and on extremities were detected. Microscopic examination of skin scrapings taken from pinnae and hair plucked from the medial extremities region revealed the presence of Psoroptes $s p$. The ventral abdominal and extremitas localization of Psoroptes $s p$. was evaluated as an ectopic infestation. To our knowledge, this is the first report of Psoroptes $s p$. in Sulawesi Bear Cuscus (Ailurops ursinus) in Indonesia. The Sulawesi bears cuscus were injected subcutaneously with ivermectin at $0.1 \mathrm{mg} / \mathrm{kg}$ of bodyweight, as well as with injected intramusculary a ADE combination to supportive therapy. Three Sulawesi Bears Cuscus became negative for mites after third treatments of ivermectin at seven days interval, and clinical mange did not recur.
\end{abstract}

Keywords: Psoroptes sp., infestation, Sulawesi bear cuscus (Ailurops ursinus)

\section{Introduction}

Diseases of the sulawesi bear cuscus (Ailurops ursinus) rare published. The disease is one threat to the survival of possum if not handled properly and wildlife (Pederson et al., 2007). Sulawesi bear cuscus (Ailurops ursinus) is one of the animal species endemic to the island of Sulawesi, which is protected by Indonesian Government Regulation Number. 7/1999. These animals included in the red list of threatened species IUCN 2008 (Salas et al., 2008). Sulawesi bear cuscus is an animal marsupial and from family Phalangeridae.

Report cases of disease caused Psoroptes sp. the possum has not been published, one of a kind Psoroptes is Psoroptes cuniculi generally attacks on domesticated livestock such as rabbits (Acar et al., 2007; Kyung-Yeon \& Oh-Deog, 2010), Psoroptes is the causative agent of dermatitis in cattle, sheep, goats, rabbits and turkey (Kurtdede et al., 2007; Lekimme et al., 2008). Type P. cuniculi attack on wildlife group Artiodactyls reported by Pederson et al. (2007), whereas the incidence of deer in the United States reported by Schmith et al. (1982).

This mite has a host of high specification. Psoroptes species that normally live on the host will not infest other host with different species. Psoroptes do not dig a tunnel under the skin and only live on the surface, under the scab, and under the accumulated pile of scaly skin, outer ear, auditory canal, and obtain food by piercing the skin (Bowman, 1999).

\section{Case History and clinical examination}

One male and two female sulawesi bear cuscus (Ailurops ursinus), weighing 4.4, 5.1 and 4.6 kg was admitted to the Animal Health Center of the Agriculture Extension College, Gowa from Gowa Discovery Park (GDP). Cuscus presented pruritis, alopecic and weight loss. Clinical examination revealed severe bilateral lesions in both pinnae, and erythematous, and alopecic skin lesions with pruritis on the ventral abdomen, perianal and extremities (Figure $1)$. 


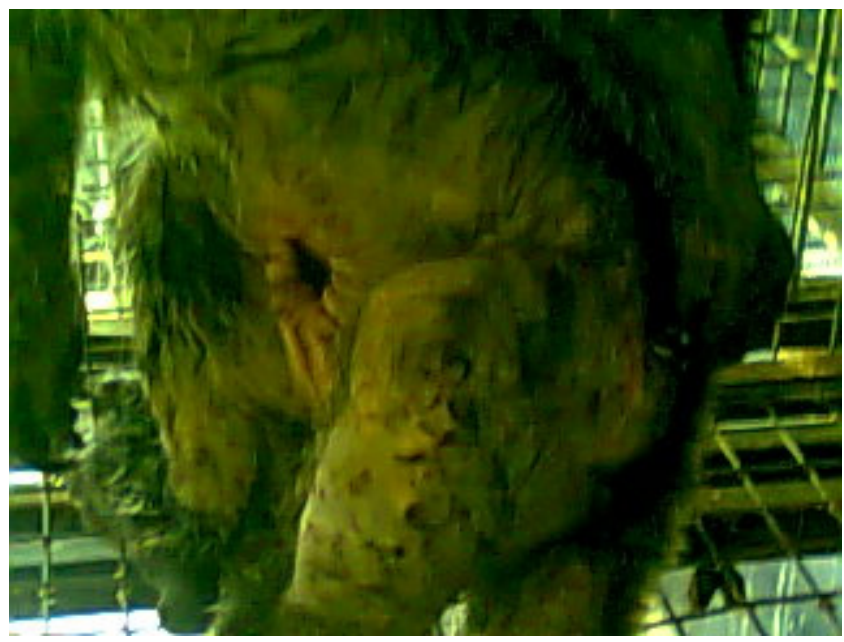

Figure 1. Infection showing spread in extremitas, ventral abdomen and tail

\section{Diagnosis}

Diagnosis was performed by clinical signs, dermatological and microscopic examination of the skin lesions. Microscopic examination of skin scrapings taken from pinnae and hair plucked from the medial extremities region revealed the presence of Mange. Many mites were detected on microscopic examination of material scraped from the external ventral abdominal and extremitas. Skin scrapings from each region then included in a separate vial containing a solution $\mathrm{KOH} 10 \%$. Identification is done under a microscope. Results identification diagnosed as Psoroptes sp. (Figure 2).

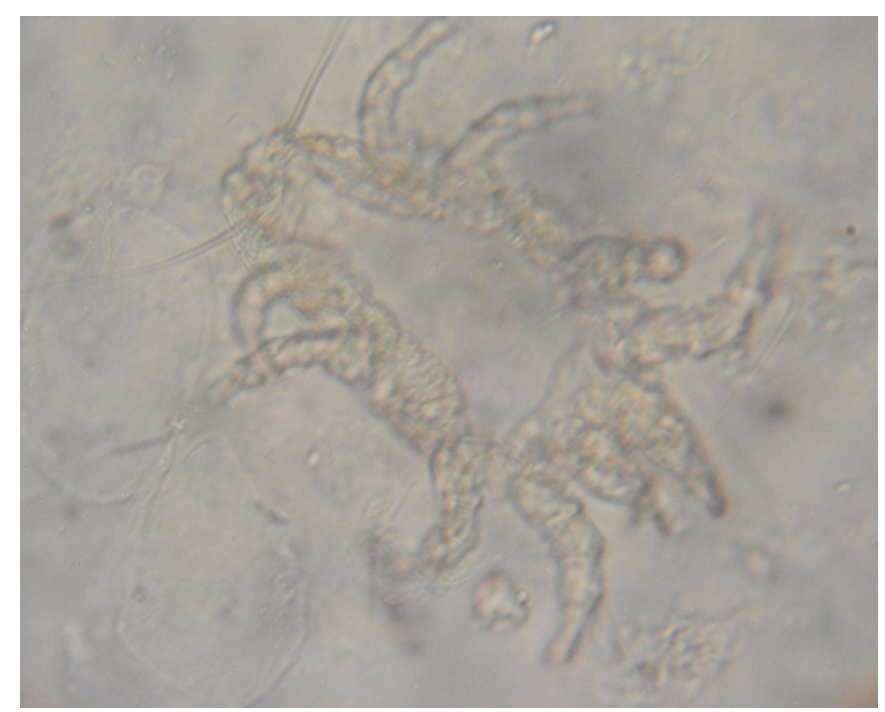

Figure 2. Microscopic examination of skin sample from ventral abdomen of cuscus observes the mite Psoroptes sp.

Psoroptes sp. has an oval body shape and length of the section conical front. Psoroptes has a long pedicle connected to the carancula. Mites large female with a body length of about $750 \mu \mathrm{m}$. Tarsi I and II culminate in karankula while the tarsi III with the same limb size led to long setae (Wall \& Shearer, 1997).

\section{Treatment}

The cuscuses were injected subcutaneously with ivermectin at $0.1 \mathrm{mg} / \mathrm{kg}$ of body weight, as well as with injected intramusculary a ADE combination to supportive therapy. Three cuscus became negative for mites after third treatments of ivermectin at seven days interval, and clinical mange did not recur. 


\section{Discussion}

Based on the results of a physical examination on cuscus, there is a dominant lesions include alopecia and purities at the ventral abdominal, extremity, lightly hooked around the eyes and the base of the ear. This is in contrast to the infestation P.caniculi on a change in the dominant rabbit ears, however, in many cases Psoroptes affected mainly in area of ear, head, neck, abdomen, legs and perianal region of farm rabbits reported severe itching, infections, lesions and swelling. In older or sick animals, or if not treated properly, the parasite can spread to other regions on the body. The mite $P$. cuniculi is a worldwide obligatory ectoparasite, mainly of rabbits, goats, horses, and sheep (Perrucci et al., 2005). Diagnosis of mange is achieeved through observation of clinical signs e.g. itching, pruritis, and wool loss and ultimately through the detection of mites in skin scrapings. Early stages of infestation are often difficult to diagnose and subclinical animals can be a major factor in disease spread (Burgess et al., 2012).

The mites puncture the epidermis of ear, suck lymph and give rise to local inflammatory swelling from which serum exude, coagulates and forms enormous encrustation inside the ear. The mite causes intense pruritus with formation of crusts and scabs, which can completely fill the external ear canal and internal surface of the pinnae in untreated animals (Perrucci et al., 2005). In the rabbit, it is important to mention that in present study, lesions in the experimental infestation with the mite werw detected after 21 day post infestation (Hallal-Calleros et al., 2013) However, this study, Cuscus presented pruritis, alopecic and weight loss. Clinical examination revealed severe bilateral lesions in both pinnae, and erythematous, and alopecic skin lesions with pruritis on the ventral abdomen, perianal and extremities (Figure 1). Many cases Psoroptes affected mainly in area of ear, head, neck, abdomen, legs and perianal region of farm rabbits reported severe itching, infections, lesions and swelling (Swarnakar et al., 2014).

According to Jeesup and Boyce (2008), ivermectin administered SC $0.2 \mathrm{mg} / \mathrm{kg}$ effective controlling Psoroptes infestations in cattle, but this formulation has been ineffective in infested big-horn sheep. Our preliminary studies with both domestic and big-horn sheep have indicated that higher doses of ivermectin (from 0.8 to $1 \mathrm{mg} / \mathrm{kg}$ ) are requred to achive serum levels comparable to those that are miticidal in cattle. In this case report, the dose used $0.1 \mathrm{mg} / \mathrm{kg}$, with consideration has not been reported on the use of ivermectin cuscus, contraindications arise feared or other side effects adverse. Giving the injection of vitamin ADE as supportive therapy to improve growth, enhance immunity against the disease, especially in young animals, help recovering from illness, and cope with hair loss. Treatment is quite effective in controlling infestations Psoroptes $s p$. after 3 repetitions with 1-week intervals, characterized by microscopic examination of skin scrapings not found Psoroptes sp., healing is also characterized by the growth of the region experiencing hair loss (Figure 3). This is in accordance with Hillyer (1994) recommended the administration of 3 doses.

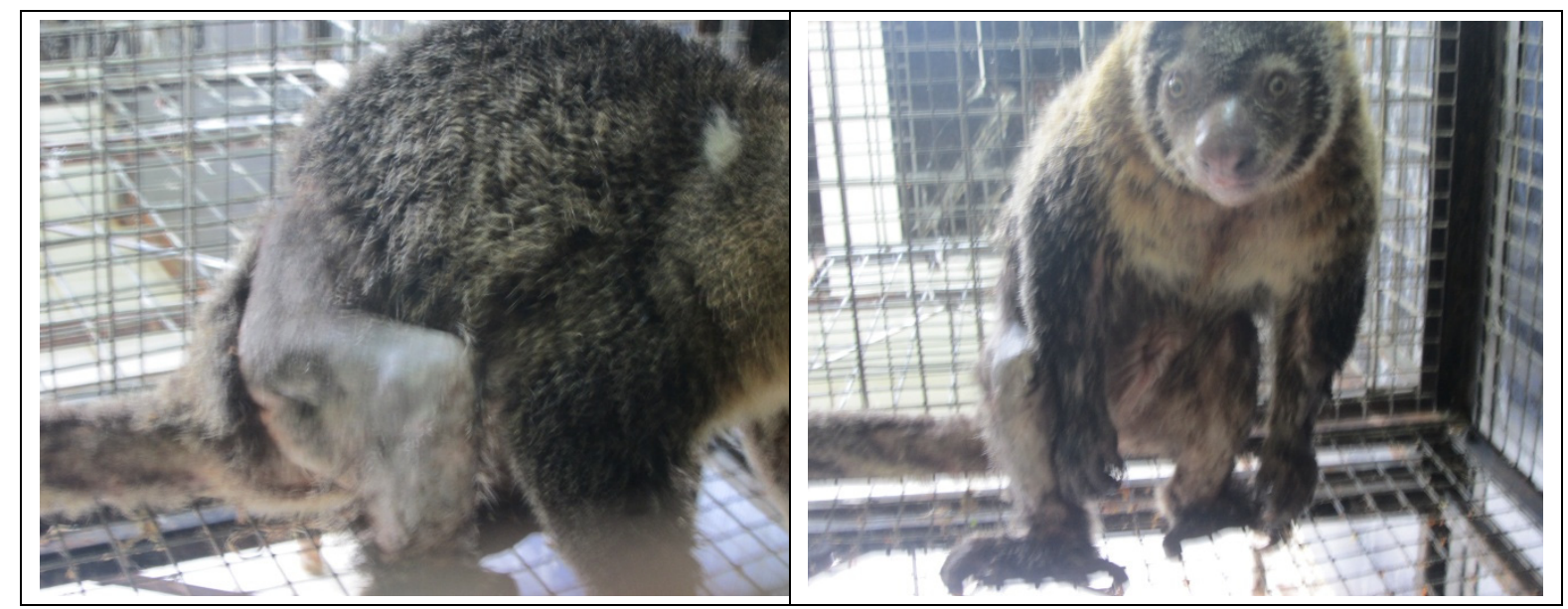

Figure 3. Cuscus after treatment with ivermectin and vitamin ADE injections every week for 3 weeks

\section{Acknowledgement}

Authors are grateful to the Operational Manager Sheila Ishak, Gowa Discovery Park (GDP) Makassar South Sulawesi-Indonesia for providing the facilities for the sample collection. 


\section{References}

Acar, A., Kurtdede, A., Ural, K., Cingi, C. C., Karakurum, M. C., Yaci, B. B., \& Sari, B. (2007). An Ectopic Case of Psoroptes cuniculi Infestation in a Pet Rabbit. Turk. J. Vet. Anim. Sci., 31(6), 423-425.

Bowman, D. D. (1999). Georgis' Parasitology for Veterinarian (8nd Ed.). Missouri (US): Saunders.

Burgess, S. T., Innocent, G., Nunn, F., Frew, D., Kenyon, F., Nisbet, A. J., \& Huntley, J. F. (2012). The use of a Psoroptes ovis serodiagnostic test for the analysis of a natural outbreak of sheep scab. Parasit Vectors, 5(7), http://dx.doi.org/10.1186/1756-3305-5-7

Hallal-Calleros, C., Morales-Montor, J., Vázquez-Montiel, J. A., Hoffman, K. L., Nieto-Rodríguez, A., \& Flores-Pérez, F. I. (2013). Hormonal and behavioral changes induced by acute and chronic experimental infestation with Psoroptes cuniculi in the domestic rabbit Oryctolagus cuniculus. Parasites \& vectors, 6(1), 361. http://dx.doi.org/ 10.1186/1756-3305-6-361

Hillyer, E. V. (1994). Pet rabbits. Vet. Clin. North Am. Small Anim. Pract., 24, 25-65.

Jessup, D. A., \& Boyce, W. M. (2008). Disease of wild sheep in Zoo and Wild Animal Medicine (6nd Ed.). In M. E. Fowler, \& R. E. Miller (Eds.). WB Saunders Company. Philadelphia, London, Colorado, Montreal, Sydney, Tokyo.

Kurtdede, A., Karaer, Z., Acar, A., Guzel, M., Cingi, C. C., Ural, K., \& Ica, A. (2007). Use of selamectin for the treatment of psoroptic and sarcoptic mite infestation in rabbits. Vet Dermatol., 18, 18-22. http://dx.doi.org/ 10.1111/j.1365-3164.2007.00563.x

Kyung-Yeon, E., \& Oh-Deog, K. (2010). Psoroptic Otocariasis Associated with Psoroptes cuniculi in Domestic Rabbits in Korea. Pak Vet J., 30(4), 251-252.

Lekimme, M., Focant, C., Farnir, F., Mignon, B., \& Losson, B. (2008). Pathogenicity and thermotolerance of entomopathogenic fungi for the control of the scab mite, Psoroptes ovis. J. Exp. Appl. Acarol., 46(1-4), 95-104. http://dx.doi.org/10.1007/s10493-008-9171-9

Pedersen, A. B., Jones, K. E., Nunn, C. L., \& Altizer, S. (2007). Infectious Diseases and Extinction in Wild Mammals. Conservation Biology, 21(5), 1269-1279. http://dx.doi.org/10.1111/j.1523-1739.2007.00776.x.

Perrucci, S., Rossi, G., Fichi, G., \& O Brien, D. J. (2005). Relationship between Psoroptes cuniculi and the internal bacterium Serratia marcescens. Exp. Appl. Acarol., 36, 199-206. http://dx.doi.org/10.1007/s10493-005 $-4511-5$

Salas, L., Dickman, C., Helgen, K., \& Flannery, T. (2008). Ailurops ursinus. In IUCN 2013. IUCN Red List of Threatened Species (Ver. 2013.2). Retrieved April 25, 2014 from www.iucnredlist.org

Schmitt, S. M., Cooley, T. M., \& Van-Veen, T. W. S. (1982). Psoroptes cuniculi in Captive White-Tailed Deer in Michigan. Journal of Wildlife Disease, 18(3), 349-351. http://dx.doi.org/10.7589/0090-3558-18.3.349

Swarnakar, G., Sharma, D., Sanger, B., \& Roat, K. (2014). Infestation of ear mites Psoroptes cuniculi on farm rabbits and its anthropozoonosis in Gudli village of Udaipur District, India. Int. J. Curr. Microbiol. App. Sci, 3(3), 651-656.

Wall, R. \& Shearer, D. (1997). Veterinary Entomology: Arthropod Ectoparasites of Veterinary Importance (1st ed.). London (GB): Chapman and Hall. http://dx.doi.org/10.1007/978-94-011-5852-7

\section{Copyrights}

Copyright for this article is retained by the author(s), with first publication rights granted to the journal.

This is an open-access article distributed under the terms and conditions of the Creative Commons Attribution license (http://creativecommons.org/licenses/by/3.0/). 